\title{
STUDIES IN THE ECONOMIC AND SOCIAL HISTORY OF PALESTINE IN THE NINETEENTH AND TWENTIETH CENTURIES
}

In spite of all the attention which the problem of Palestine has received little basic research has been undertaken on the recent economic and social history of the Arab population of the country, both before and after 1948 .

This book contains four new studies on different aspects of the subject. They include an examination of the first effects of European involvement on the urban and rural economy of Palestine during the mid-nineteenth century and a detailed analysis of socio-economic change in one very important hill region in the 1920s and 1930s: the Jabal Nablus. A third essay looks at the complicated problem of applying the concepts of 'faction' and 'class' to the study of Palestinian Arab society and Palestinian political activity, while a fourth traces the misfortunes of the villagers and refugees living along the new Israeli/Jordanian demarcation line in the years just after the 1948 war.

There is also a long introduction by the editor in which he examines the particular problems and difficulties involved in the analysis of the socio-economic history of a country which was both the colony of a great power and the site of a major attempt to establish a Jewish national home.

Dr Roger Owen, the editor of this volume, is Lecturer in the Recent Economic History of the Middle East and Fellow of St Antony's College, Oxford. He is a former Director of the Middle East Centre at St Antony's.

$\mathrm{He}$ is the author of Cotton and the Egyptian Economy, 1820-1914 and The Middle East in the World Economy, 1800-1914 and the editor or co-editor of Studies in the Theory of Imperialism, Essays in the Crisis in Lebanon and Studies in Eighteenth Century Islamic History. 
St Antony's/Macmillan Series

General editor: Archie Brown, Fellow of St Antony's College, Oxford

Archie Brown and Michael Kaser (editors) SOVIET POLICY FOR THE 1980s

S. B. Burman CHIEFDOM POLITICS AND ALIEN LAW

Wilhelm Deist THE WEHRMACHT AND GERMAN REARMAMENT

Ricardo Ffrench-Davis and Ernesto Tironi (editors) LATIN AMERICA AND THE NEW INTERNATIONAL ECONOMIC ORDER

Bohdan Harasymiw POLITICAL ELITE RECRUITMENT IN THE USSR

Richard Holt SPORT AND SOCIETY IN MODERN FRANCE Albert Hourani EUROPE AND THE MIDDLE EAST THE EMERGENCE OF THE MODERN MIDDLE EAST

Paul Kennedy and Anthony Nicholls (editors) NATIONALIST AND RACIALIST MOVEMENTS IN BRITAIN AND GERMANY BEFORE 1914

Richard Kindersley (editor) IN SEARCH OF EUROCOMMUNISM Gisela C. Lebzelter POLITICAL ANTI-SEMITISM IN ENGLAND, 1918-1939

C. A. MacDonald THE UNITED STATES, BRITAIN AND APPEASEMENT, 1936-1939

Patrick O'Brien (editor) RAILWAYS AND THE ECONOMIC DEVELOPMENT OF WESTERN EUROPE, 1830-1914

Roger Owen (editor) STUDIES IN THE ECONOMIC AND SOCIAL HISTORY OF PALESTINE IN THE NINETEENTH AND TWENTIETH CENTURIES

Irena Powell WRITERS AND SOCIETY IN MODERN JAPAN

T. H. Rigby and Ferenc Fehér (editors) POLITICAL LEGITIMATION IN COMMUNIST STATES Marilyn Rueschemeyer PROFESSIONAL WORK AND MARRIAGE: AN EAST-WEST COMPARISON

A. J. R. Russell-Wood THE BLACK MAN IN SLAVERY AND FREEDOM IN COLONIAL BRAZIL

David Stafford BRITAIN AND EUROPEAN RESISTANCE, 1940-1945

Nancy Stepan THE IDEA OF RACE IN SCIENCE

Guido di Tella ARGENTINA UNDER PERÓN, 1973-76

Rosemary Thorp and Laurence Whitehead (editors) INFLATION AND STABILISATION IN LATIN AMERICA

Rudolf L. T6kés (editor) OPPOSITION IN EASTERN EUROPE 


\section{Studies in the Economic and Social History of Palestine in the Nineteenth and Twentieth Centuries}

Edited by

ROGER OWEN

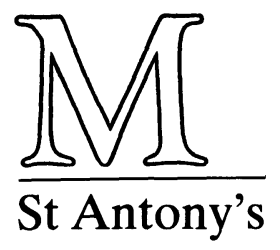


(C) St Antony's College, Oxford, 1982

Softcover reprint of the hardcover 1st edition 1982 978-0-333-30079-4

All rights reserved. No part of this publication may be reproduced or transmitted, in any form or by any means, without permission

First published 1982 by THE MACMILLAN PRESS LTD

London and Basingstoke Companies and representatives throughout the world

ISBN 978-1-349-05702-3

ISBN 978-1-349-05700-9 (eBook)

DOI 10.1007/978-1-349-05700-9 


\section{Contents}

List of Tables, Figures and Maps vi

Preface ix

Notes on the Contributors $\quad \mathbf{x}$

Note on Transliteration $\quad \mathrm{xi}$

The Maps xii

Introduction 1

ROGER OWEN

1. European Penetration and the Economic Development of Palestine, $1856-82$

ALEXANDER SCHÖLCH

2. The Political Economy of the Jabal Nablus, 1920-48 88 SARAH GRAHAM-BROWN

3. Factionalism and Class Formation in Recent Palestinian History

SALIM TAMARI

4. The Palestinians of Jordan's Border AVI PLASCOV

Index 


\section{List of Tables, Figures and Maps}

\section{TABLES}

1.1 Population of the towns of Palestine in the nineteenth century

1.2 Average annual export of the main articles from Jaffa, Haifa and Acre

1.3 Main export articles of Jaffa (by quantity)

1.4 Value of the three main export articles of Jaffa in various years and their percentage of total exports

1.5 Main export articles of Acre, $1872-80$ (by quantity)

1.6 Main export articles of Haifa, 1872-80 (by quantity)

1.7 Cotton exports from Acre and Haifa, 1852-62

1.8 Estimate of the average proportion of northern Palestine's cultivated area devoted to certain crops, 1858-62

1.9 Increase in exports of main export articles from Jaffa (by quantity)

1.10 Exports and imports of Jaffa (value in PT)

1.11 Value of exports and imports of Jaffa, 1876-82, according to non-British consular reports

1.12 Average value of export prices at Jaffa by quarter and year (in PT)

1.13 Average annual export prices at Acre, Haifa and Jaffa (in PT)

1.14 Consumer prices in Jerusalem, 1858 and 1880 (in PT) 66

1.15 Main imports at Jaffa, 1874-7 and 1879-82 (in PT) 67

1.16 Daily wages in the building industry in Jerusalem, 1861-3 68 
1.17 Occupational structure of the population in Jerusalem in 1877

1.18 Traffic between Jaffa and Jerusalem in 1877

1.19 Annual income from transport between Jaffa and Jerusalem in 1881 (£T)

1.20 Occupational structure in Bethlehem (about 1890)

72

1.21 Occupational structure of Nazareth in 1890

2.1 The redemption prices of six major Palestinian crops on which the tithe was commuted, 1924-7 and their market price in July 1930

2.2 Share of Jews, Arabs and others in Palestine's foreign assets, 1946

2.3 Percentage of population of the sub-districts of Nablus, Tulkarm and Jenin dependent on agriculture for their livelihood, 1931

2.4 The relationship of peasant population to agricultural land in the Jenin sub-district

2.5 Stages of settlement work reached in the 167 villages brought under settlement at the end of 1935

2.6 Number of privately-owned parcels of land in five villages, distributed according to the number of owners of each parcel, 1944

2.7 Estimates of the average cost of agricultural production, of income and profit, 1930

2.8 Income and expenditure of an 'ordinary fellah' according to Wilkansky (area 80-100 dunums)

2.9 Olive propagation: olive trees planted by the government according to source, 1924/5-1936/7

2.10 Wholesale prices of Nablusi soap compared with that of the Shemen factory, 1929-40 (£P per 100 kilos)

2.11 Exports of soap from Palestine, 1928-40

2.12 Average wages paid to labour per 9-hour day in 1929 (skilled and semi-skilled work)

2.13 Estimates of wage labour employed outside the village in two Palestinian sub-districts during World War II

2.14 Source of income for wage-earners in three Palestinian sub-districts, 1931

2.15 Estimated production of Palestinian crops for the years $1927-42$

2.16 Domestic expenditures of various colonial governments in the interwar period by purpose (per cent) 
viii

\section{FIGURES}

2.1 Types of Share Contract

\section{MAPS}

1. Northern Palestine

xii

2. Central and Southern Palestine

xiii

3. The Arab border villages showing the 1949 Armistice line 


\section{Preface}

The four essays which form this volume were all written by friends and colleagues with some connection with the Middle East Centre of St Antony's College, whether as students, academic visitors or contributors to seminars. Although each piece of research was originally intended to stand in its own right it is my belief that, taken together, they constitute an important contribution to the study of the modern economic and social history of Palestine.

I was distressed to learn of the tragic and untimely death of Avi Plascov during the proofing of the book. I wish he had lived to see it.

Roger Owen 


\section{Notes on the Contributors}

SARAH GRAHAM-BROWN works for the Middle East Economic Digest. She is the author of Palestinians and their Society 1880-1946 (London, 1981).

DR AVI PLASCOV, who received his doctorate from the School of Oriental and African Studies of the University of London, was a Research Associate, 1978-80, and in 1981 was a Visiting Fellow of the International Institute for Strategic Studies, London. At the time of his death he was at the Centre for Strategic Studies and the Shiloah Center for Middle Eastern and African Studies at Tel Aviv University. He was the author of The Palestine Refugees in Jordan, 1948-57 (London, 1981) and 'A Palestinian State? Examining the Alternatives', Adelphi Papers, no. 163 (IISS). His book, Security in the Persian Gulf: Modernization, Political Development and Stability is to be published shortly.

DR ALEXANDER SCHÖLCH teaches the modern history of the Middle East at the University of Essen. He is the author of Ägypten den Agyptern: Die politische und gesellschaftliche Krise der Jahre 1878-1881 in Agypten (Zurich and Freiberg, 1976), translated as Egypt for the Egyptians (London, 1981).

SALIM TAMARI teaches sociology at Bir Zeit University. 


\section{Note on Transliteration}

Arabic words and proper nouns have been presented in as simple a form as possible. Those which can be found in The Shorter Oxford Dictionary have been presented in their anglicised form (thus, for example, fellaheen, feddan). Place names are given according to the way they appeared on the official maps produced by the Government of Palestine before 1948. Other words and names have been transliterated according to the method to be found in Wehr's Arabic Dictionary, but without diacriticals except in the case of the names of authors and titles to be found in the Notes and References sections, where ayns and hamzas have been used. 


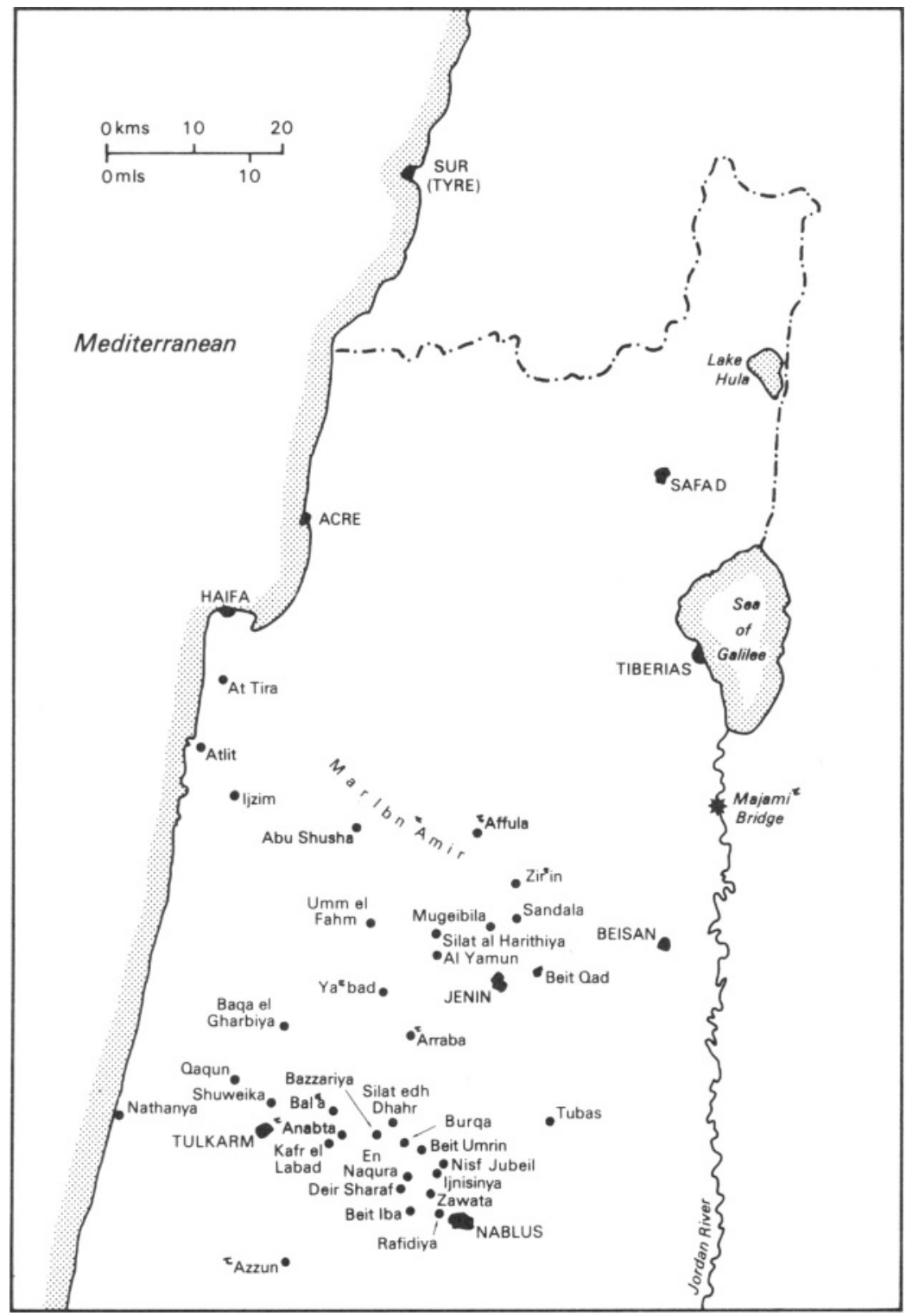

\section{MAP 1 Northern Palestine}




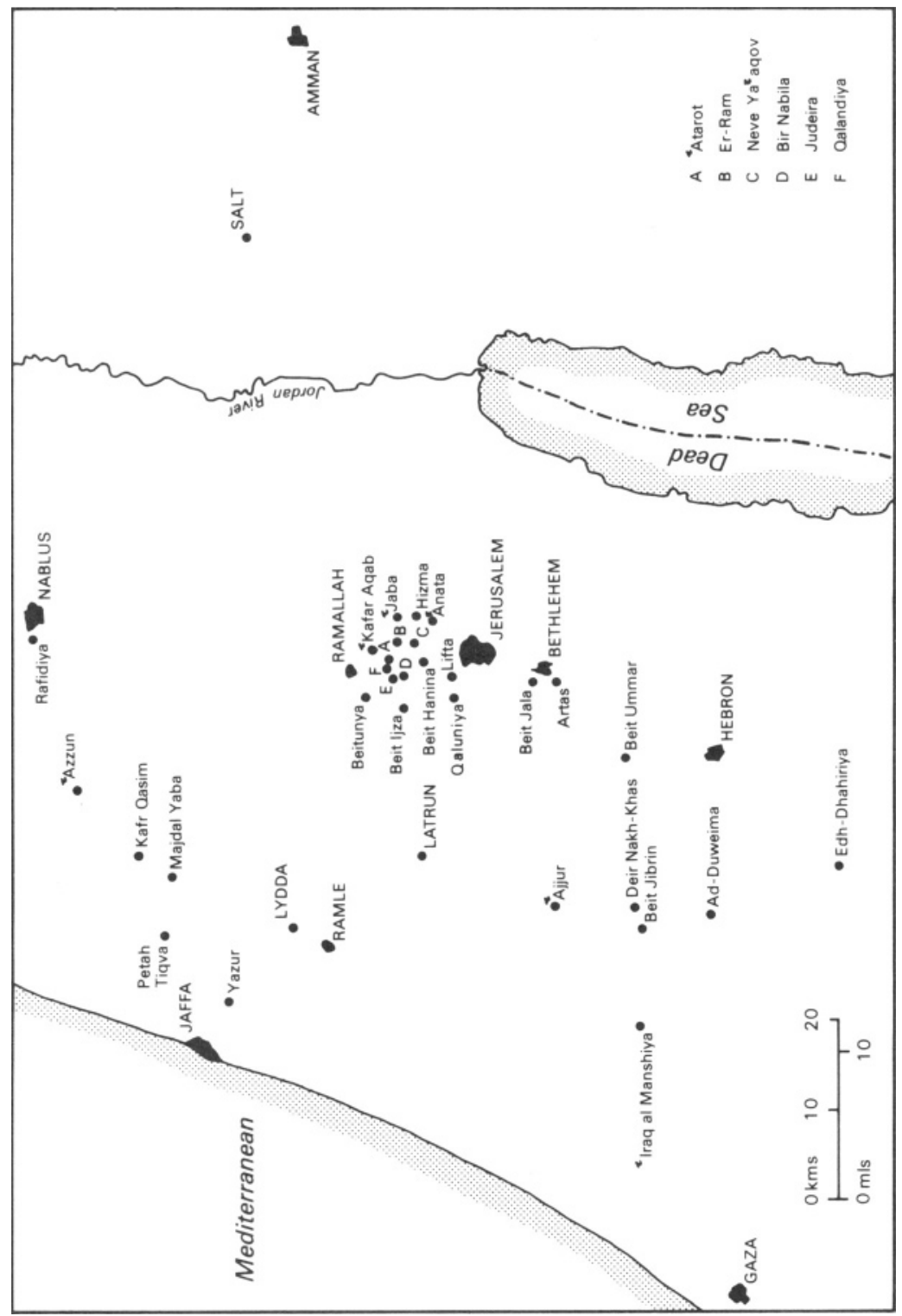

MAP 2 Central and Southern Palestine 
xiv

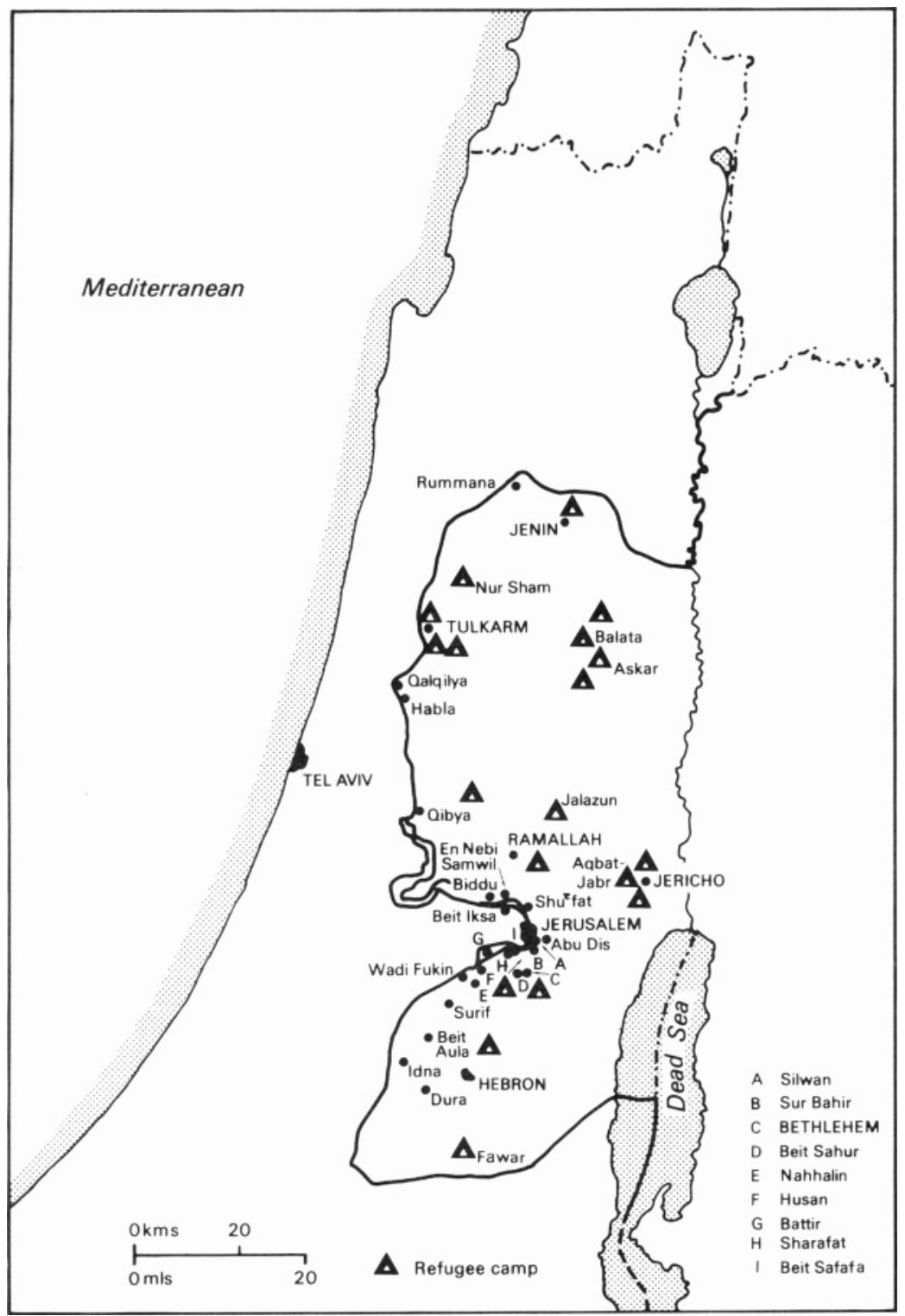

MAP 3 The Arab border villages showing the 1949 Armistice line 